\title{
Comparison of Historical Streamflows to 2013 Streamflows in the Williamson, Sprague, and Wood Rivers, Upper Klamath Lake Basin, Oregon
}

By Glen W. Hess and Adam Stonewall.

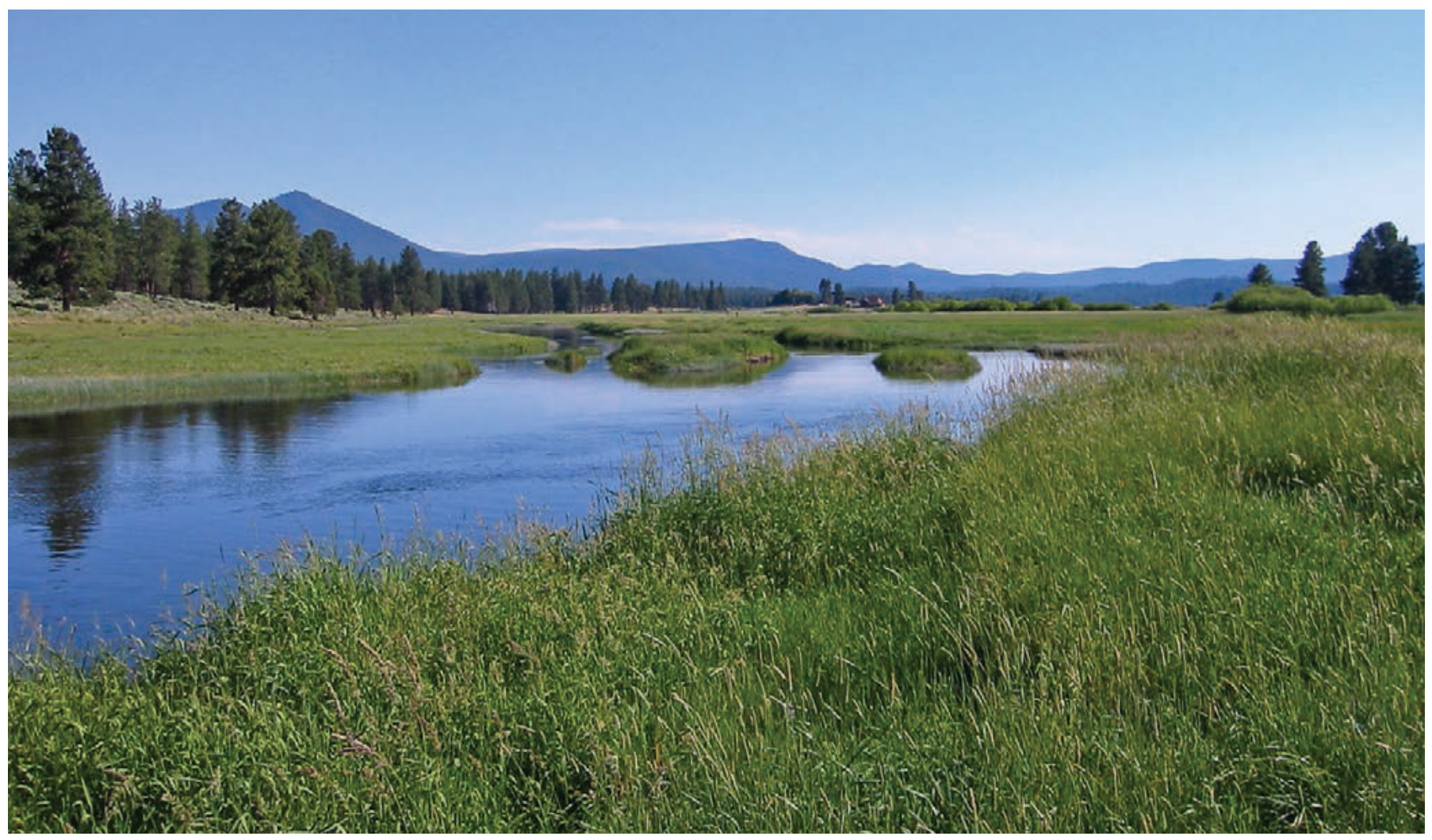

Prepared in cooperation with the Bureau of Reclamation

Open-File Report 2014-1128

U.S. Department of the Interior

U.S. Geological Survey 
Cover: Sprague River at Kamkaun Springs, Upper Klamath Lake Basin, Oregon (Photograph by Jim O'Connor, U.S. Geological Survey) 


\section{Comparison of Historical Streamflows to 2013 Streamflows in the Williamson, Sprague, and Wood Rivers, Upper Klamath Lake Basin, Oregon}

By Glen W. Hess and Adam Stonewall

Prepared in cooperation with the Bureau of Reclamation

Open File Report 2014-1128 


\title{
U.S. Department of the Interior SALLY JEWELL, Secretary
}

\author{
U.S. Geological Survey \\ Suzette M. Kimball, Director
}

U.S. Geological Survey, Reston, Virginia: 2014

For more information on the USGS—-the Federal source for science about the Earth, its natural and living resources, natural hazards, and the environment-visit

http://www.usgs.gov or call 1-888-ASK-USGS

For an overview of USGS information products, including maps, imagery, and publications, visit $h$ ttp://www.usgs.gov/pubprod

To order this and other USGS information products, visit http://store.usgs.gov

Suggested citation:

Hess, G.W., and Stonewall, Adam, 2014, Comparison of historical streamflows to 2013 streamflows in the Williamson, Sprague, and Wood Rivers, Upper Klamath Lake Basin, Oregon: U.S. Geological Survey Open-File Report 2014-1128, 23 p., http://dx.doi.org/10.3133/ofr20141128

ISSN 2331-1258 (online)

Any use of trade, firm, or product names is for descriptive purposes only and does not imply endorsement by the U.S. Government.

Although this information product, for the most part, is in the public domain, it also may contain copyrighted materials as noted in the text. Permission to reproduce copyrighted items must be secured from the copyright owner. 


\section{Contents}

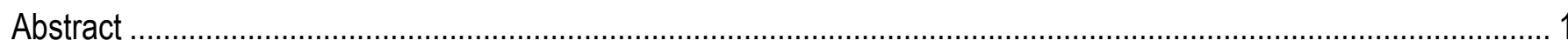

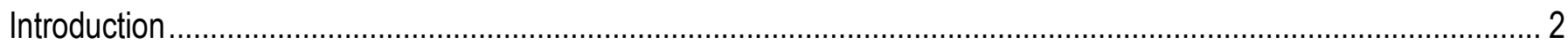

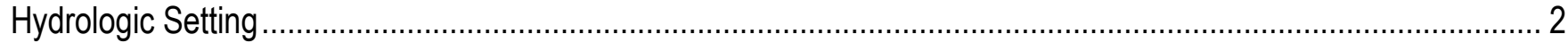

Purpose and Scope

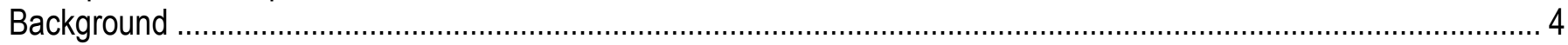

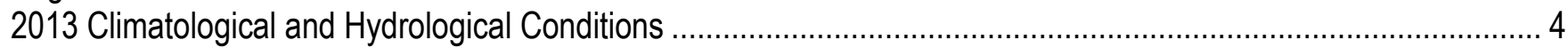

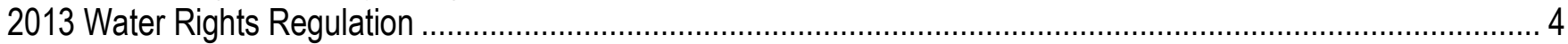

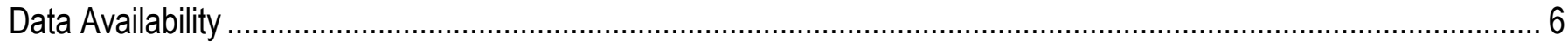

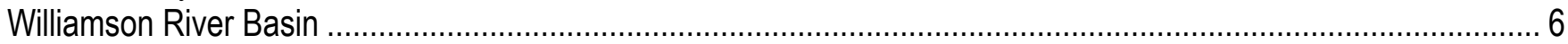

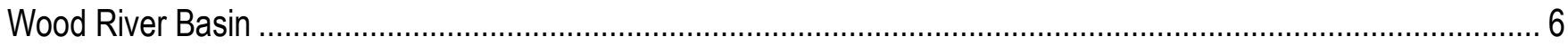

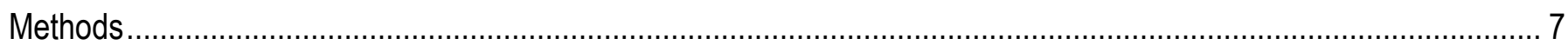

Definition of Hydrographs Used in the Analysis ......................................................................................

Development of the Composite Index Year for the Streamflow and Baseflow Methods.......................................... 9

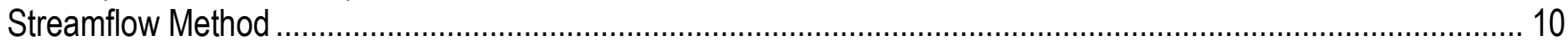

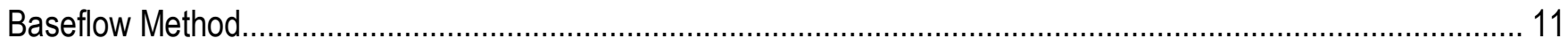

Miscellaneous Streamflow Measurement Method for the Wood River Basin ...................................................... 14

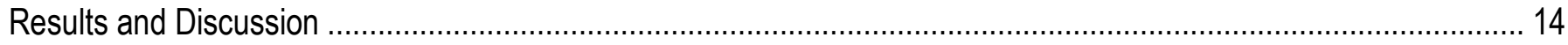

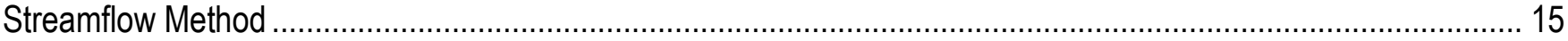

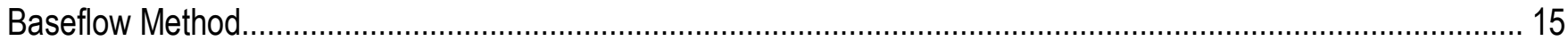

Miscellaneous Streamflow Measurement Method for the Wood River Basin ..................................................... 16

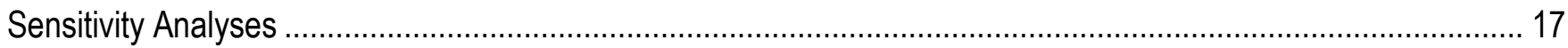

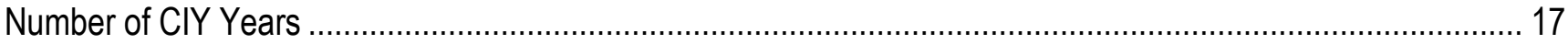

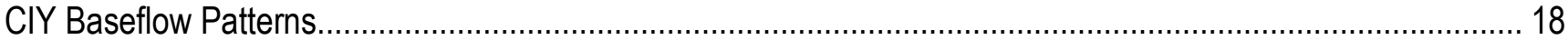

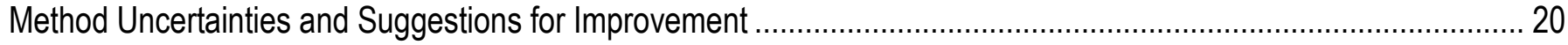

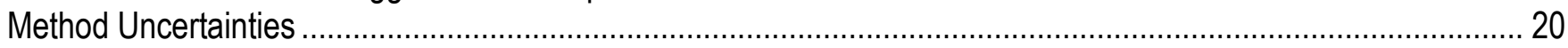

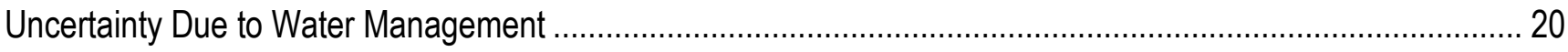

Uncertainty Due To Climatic Variation or Land-Use Changes...................................................................... 21

Suggestions for Improvement: Data Needs for Refining Streamflow Estimates .................................................. 21

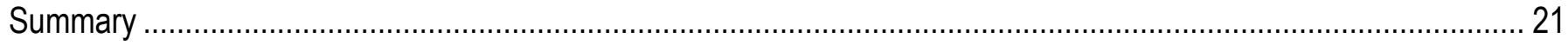

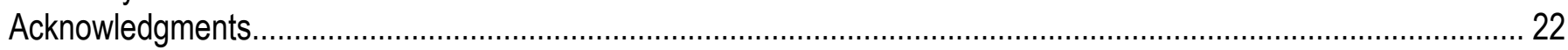

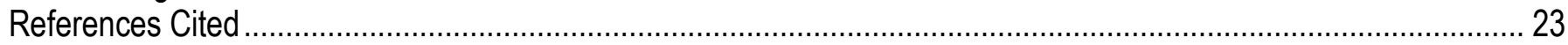

\section{Figures}

Figure 1. Upper Klamath Lake Basin, Oregon, and streamflow measurement stations used or considered for this study.

Figure 2. Streamflow and hydrologic periods at the Sprague River near Chiloquin streamflow gage (11501000) in the Upper Klamath Lake Basin, Oregon, May-October, 2013

Figure 3. Measured 2013 baseflow hydrograph, composite index year baseflow (CIY) hydrograph, and component years of the ClY baseflow hydrographs for the Sprague River streamflow gage, Upper Klamath Lake Basin, Oregon.

Figure 4. Comparison of 2013 measured streamflow to CIY streamflow at the Sprague River streamflow gage, Upper Klamath Lake Basin, Oregon. 
Figure 5. Comparison of measured 2013 streamflow to calculated 2013 baseflow for the Sprague River streamflow gage (11501000), Upper Klamath Lake Basin, Oregon.

Figure 6. Comparison of 2013 baseflow and CIY baseflow at the Sprague River gage, Upper Klamath Lake Basin, Oregon.

Figure 7. Comparison of the dryness rank of the May-June streamflow for the Sprague and Chewaucan River streamflow gages for 1972-2012.

\section{Tables}

Table 1. Streamflow-data-collection sites in and near the Upper Klamath Lake Basin, Oregon, used for this study.. 7 Table 2. Best-fit evaluation of candidate years for Sprague gage (station 11501000) baseflows for the Composite Index Year, May 1-June 15

Table 3. Estimated increase in summer 2013 streamflow from regulation of diversions in the Sprague and Wood River Basins Upper Klamath Lake Basin, Oregon.

Table 4. Comparison of Wood River streamflow near the mouth (11504115) for the 2003-2013 irrigation seasons in the Upper Klamath Lake Basin, Oregon.

Table 5. Results of the number of years in the CIY sensitivity analysis for the Baseflow Method of determining streamflow increases resulting from regulation of diversions in the Sprague River Basin, Oregon, in 2013.

Table 6. Results of the ranking of CIY sensitivity analysis for the Streamflow and Baseflow Methods of determining streamflow increases as a result of diversion regulation in the Sprague River Basin, Oregon, in 2013.

\section{Conversion Factors and Datums}

Inch/Pound to SI

\begin{tabular}{lcl}
\hline \multicolumn{1}{c}{ Multiply } & \multicolumn{1}{c}{ By } & \multicolumn{1}{c}{ To obtain } \\
\hline foot (ft) & Length & \\
mile (mi) & 0.3048 & meter $(\mathrm{m})$ \\
\hline & 1.609 & kilometer $(\mathrm{km})$ \\
\hline square mile $\left(\mathrm{mi}^{2}\right)$ & Area & \\
\hline acre-foot $(\mathrm{acre}-\mathrm{ft})$ & 2.590 & square kilometer $\left(\mathrm{km}^{2}\right)$ \\
\hline & 1,233 & cubic meter $\left(\mathrm{m}^{3}\right)$ \\
\hline cubic foot per second $\left(\mathrm{ft}^{3} / \mathrm{s}\right)$ & Flow rate & \\
\hline
\end{tabular}

Vertical coordinate information is referenced to the North American Vertical Datum of 1988 (NAVD 88). Horizontal coordinate information is referenced to the North American Datum of 1983 (NAD 83). 


\title{
Comparison of Historical Streamflows to 2013 Streamflows in the Williamson, Sprague, and Wood Rivers, Upper Klamath Lake Basin, Oregon
}

\author{
By Glen W. Hess and Adam Stonewall
}

\section{Abstract}

In 2013, the Upper Klamath Lake Basin, Oregon, experienced a dry spring, resulting in an executive order declaring a state of drought emergency in Klamath County. The 2013 drought limited the water supply and led to a near-total cessation of surface-water diversions for irrigation above Upper Klamath Lake once regulation was implemented. These conditions presented a unique opportunity to understand the effects of water right regulation on streamflows.

The effects of regulation of diversions were evaluated by comparing measured 2013 streamflow with data from hydrologically similar years. Years with spring streamflow similar to that in 2013 measured at the Sprague River gage at Chiloquin from water years 1973 to 2012 were used to define a Composite Index Year (CIY; with diversions) for comparison to measured 2013 streamflows (no diversions). The best-fit 6 years (1977, 1981, 1990, 1991, 1994, and 2001) were used to determine the CIY.

Two streams account for most of the streamflow into Upper Klamath Lake: the Williamson and Wood Rivers. Most streamflow into the lake is from the Williamson River Basin, which includes the Sprague River. Because most of the diversion regulation affecting the streamflow of the Williamson River occurred in the Sprague River Basin, and because of uncertainties about historical flows in a major diversion above the Williamson River gage, streamflow data from the Sprague River were used to estimate the change in streamflow from regulation of diversions for the Williamson River Basin. Changes in streamflow outside of the Sprague River Basin were likely minor relative to total streamflow.

The effect of diversion regulation was evaluated using the "Baseflow Method," which compared 2013 baseflow to baseflow of the CIY. The Baseflow Method reduces the potential effects of summer precipitation events on the calculations. A similar method using streamflow produced similar results, however, despite at least one summer precipitation event. The result of the analysis estimates that streamflow from the Williamson River Basin to Upper Klamath Lake increased by approximately 14,100 acre-feet between July 1 and September 30 relative to prior dry years as a result of regulation of surfacewater diversions in 2013.

Quantifying the change in streamflow from regulation of diversion for the Wood River Basin was likely less accurate due to a lack of long-term streamflow data. An increase in streamflow from regulation of diversions in the Wood River Basin of roughly 5,500 acre-feet was estimated by comparing the average August and September streamflow in 2013 with historical August and September streamflow.

Summing the results of the estimated streamflow gain of the Williamson River Basin (14,100 acre-feet) and Wood River (5,500 acrefeet) gives a total estimated increase in streamflow into Upper Klamath Lake resulting from the July 1-September 2013 regulation of diversions of approximately 19,600 acre-feet. 


\section{Introduction}

The Upper Klamath Lake Basin in southcentral Oregon (fig. 1) is bordered on the west by the Cascade Range and the east by volcanic uplands. Much of the $3,810 \mathrm{mi}^{2}$ basin is high desert and receives little direct precipitation (Gannett and others, 2007). Water in the basin comes mainly from snowmelt runoff from the Cascades and uplands, and is used for agricultural irrigation, extensive waterfowl refuges, and support of aquatic wildlife in lakes and streams in the basin and downstream.

The agricultural economy of the Upper Klamath Lake Basin relies heavily on irrigation water. Upstream of Upper Klamath Lake, irrigation water comes primarily from surfacewater diversions in the Wood, Williamson, and Sprague River Basins, and also from groundwater. South of the study area, the lake provides irrigation water to the Bureau of Reclamation's Klamath Project. In recent years, Endangered Species Act Biological Opinions have required the Bureau of Reclamation to maintain prescribed minimum lake levels in Upper Klamath Lake to protect habitat for the endangered Lost River and shortnose suckers while at the same time maintaining specified streamflows in the Klamath River below the lake to provide habitat for Endangered Species Act listed salmon. Drought in the basin increases the competition between agricultural and environmental needs for limited water supplies.

In June 2013, streamflow in the Williamson River was below the 10th percentile, resulting in a water-supply shortage (Natural Resources Conservation Service, 2013a). On June 10, 2013, the Oregon Water Resources Department (OWRD) received a "call” from the Klamath Tribes requesting enforcement of their senior water rights (Klamath Tribes, 2013). The 2013 drought in the Upper Klamath Basin limited the water supply and led to a near-total curtailment of surface-water irrigation diversions from Upper Klamath Lake and its tributaries. This curtailment of surface-water diversions was an opportunity to evaluate the effects of water-right regulation on Upper Klamath Lake Basin streamflows and the resultant yield to Upper Klamath Lake, which is the subject of this report.

\section{Hydrologic Setting}

Principal tributary streams to Upper Klamath Lake are the Williamson River, which drains the northeastern part of the basin; the Sprague River (a major tributary to the Williamson) and its major tributary, the Sycan River, which together drain the eastern side of the basin; and the Wood River, which originates from large springs north of the lake (fig. 1). Together, these streams contribute about two-thirds of the annual streamflow into Upper Klamath Lake (Hubbard, 1970). The Sprague River provides a substantial part of the total Williamson River streamflow on an annual basis. Spring Creek, a springfed tributary in the lower Williamson River, provides most of the Williamson River streamflow near the mouth during the late summer, when a large portion of the Sprague River streamflow is diverted for irrigation in normal years. 


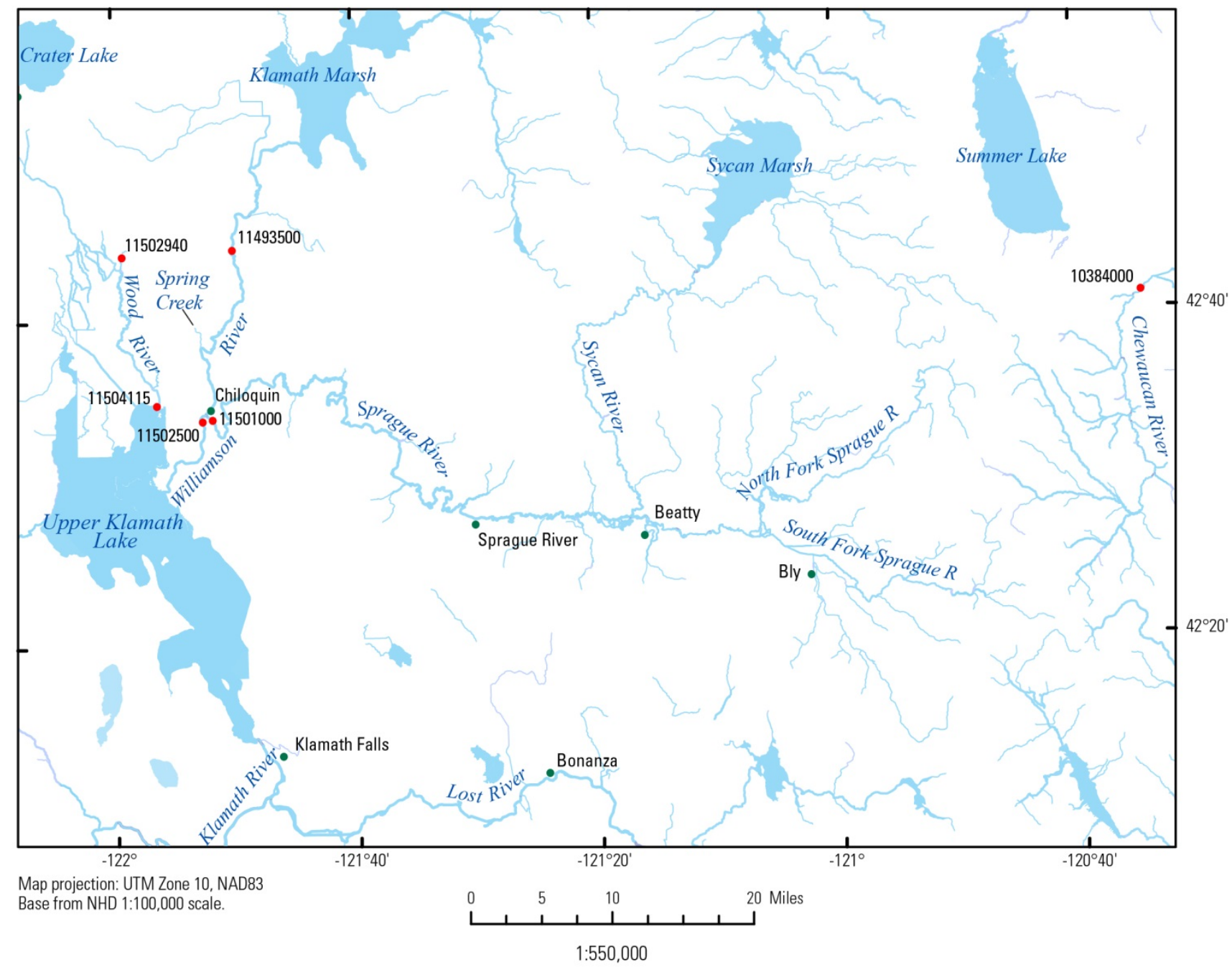

\section{EXPLANATION}

- $\quad$ City or other populated area

- USGS Streamflow measurement 11501000 station and number

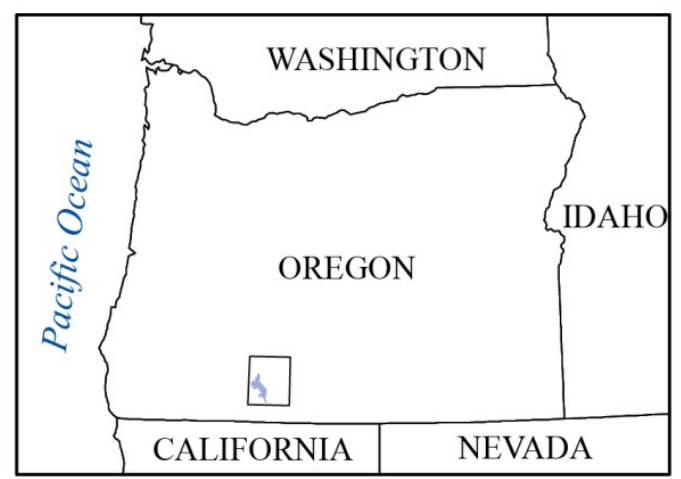

Figure 1. Upper Klamath Lake Basin, Oregon, and streamflow measurement stations used or considered for this study. 


\section{Purpose and Scope}

This report presents the results of a study to evaluate methods of quantifying the effects of the 2013 regulation of surface-water diversions on inflows to Upper Klamath Lake and provides estimates of streamflow gains resulting from that regulation. The study area includes the drainage basins of the Williamson, Sprague, and Wood Rivers. The study evaluated several methods to compare historical streamflows to 2013 streamflows to quantify the effect of the 2013 water rights regulation on inflow to Upper Klamath Lake. Historical streamflow quantification was accomplished using long-term streamflow data. Method assumptions and uncertainties are discussed.

\section{Background}

\section{Climatological and Hydrological Conditions}

In early June 2013, streamflow in the Williamson River near the mouth was below the 10th percentile, based on long-term U.S. Geological Survey (USGS) flow duration curves, The Natural Resources Conservation Service (2013a) forecasted that spring and summer streamflows would be 62 percent of average in the Williamson River Basin.

Although May precipitation was 107 percent of average, precipitation from the beginning of the water year (October 1-June 1) was 88 percent of average (Natural Resources Conservation Service, 2013b). Much of the basin was designated by the U.S. Drought Monitor (2013) in mid-June to be in a moderate drought condition, and water users in the basin expected greatly reduced streamflows in summer 2013. Streamflows in the Upper Klamath Lake Basin were not sufficient to satisfy all water rights in the basin. On June 12, 2013, OWRD began regulating Upper Klamath Lake Basin diversions to satisfy senior water rights.

\section{Water Rights Regulation}

As the 2013 priority call was implemented, irrigation diversions from streams were regulated within the Upper Klamath Lake Basin. Regulation by OWRD occurred over the following approximate 2013 periods (Kyle Gorman and Ken Stahr, OWRD, written commun., September 26, 2013):

1. Sycan River: June 12-June 17

2. Sprague River: June 17-June 28

3. Williamson River: June 28-July 8

4. Wood River: July 8-July 17

5. Other tributaries to Upper Klamath Lake: July 21-July 31.

Determining the change in streamflow to Upper Klamath Lake Basin resulting from regulation of diversions in 2013 requires either (1) knowledge of the amount of water irrigators did not divert because of regulation and the irrigation return flow (tailwater) change that resulted, or (2) the estimated streamflows if irrigation water had been diverted at normal rates in 2013. No record keeping exists for diversions; consequently, this study estimated what streamflow in 2013 would have been without regulation of diversions and compared it to past measured streamflows in years when there was no regulation. The estimated streamflow without regulation for 2013 is herein termed "CIYadjusted streamflow." (CIY=Composite Index Year; see Section "Definition of Hydrographs Used in the Analysis") To determine the effects of 2013 regulation over the irrigation period (streamflow gains), CIY-adjusted streamflows were compared to measured 2013 streamflows. The CIY-adjusted streamflows were estimated using methods that incorporated the spans of the hydrologic regulation periods for the various streams and historical streamflow data from the basin. 
For the Williamson River Basin analysis, four 2013 hydrologic periods were chosen for defining the Upper Klamath Lake inflows relative to the irrigation season (fig. 2):

1. Spring Recession-Early Irrigation: May 1-June 15; represents the period prior to regulation of diversions.

2. Regulation Transition: June 16-June 30; represents the period during which OWRD completed regulation of all water diversions from a basin stream.
3. Equilibrated Regulation: July 1-September 30 ; represents the period of effective regulation basinwide.

4. Post-Regulation: October 8-28: represents 3 weeks with little precipitation during a period when diversions were expected to be minimal.

For the Wood River Basin, the same hydrologic periods pertain, but with Equilibrated Regulation beginning August 1 and extending through September 30.

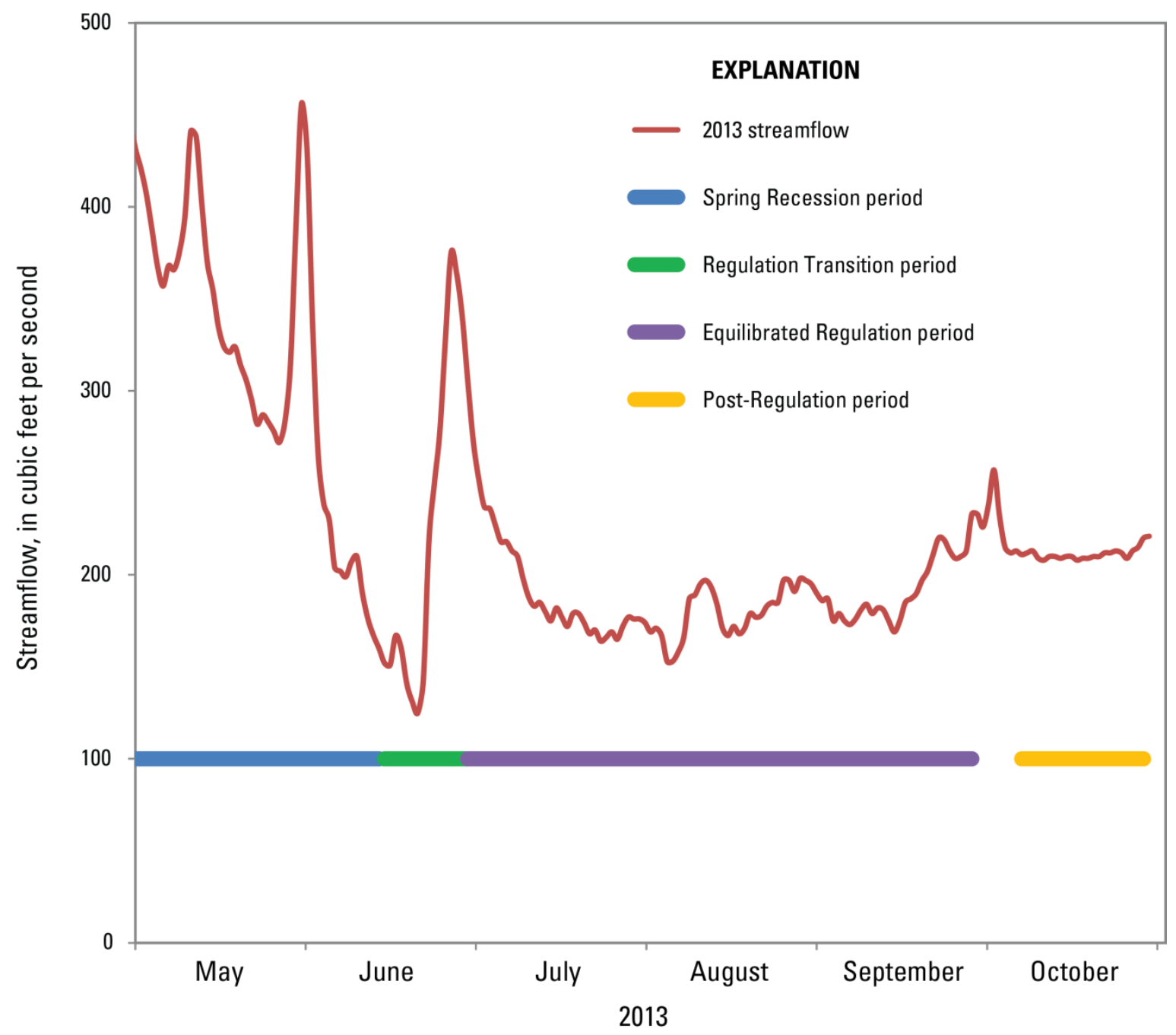

Figure 2. Streamflow and hydrologic periods at the Sprague River near Chiloquin streamflow gage (11501000) in the Upper Klamath Lake Basin, Oregon, May-October, 2013 


\section{Data Availability}

Long-term streamflow data from the Williamson River Basin and Wood River Basin were collected by the USGS and OWRD at the gage locations shown in figure 1 and listed in table 1.

\section{Williamson River Basin}

Seasonal streamflow variations in the Williamson River Basin were analyzed using data from streamflow gages on the Sprague River near Chiloquin (11501000) ("Sprague gage”), and the Williamson River below the Sprague River, near Chiloquin (11502500) ("Williamson gage"). The gages have a concurrent period of record spanning water years (WY) 1973-2013. Streamflow data from the long-term gaging station Williamson River near Klamath Agency [11493500] was not used in this analysis because there is commonly no streamflow at this site during the summer. The Sprague River is a major component of the Williamson River Basin streamflows.

Comparing long-term streamflow to 2013 streamflow at the Williamson gage is problematic because the point of diversion for the Modoc Point Irrigation District (MPID) canal, a major diversion that provides irrigation to farmland on the eastern side of the Williamson River, was moved in 2008 from the Sprague River (below the Sprague gage) to the Williamson River below the confluence with the Sprague River and below the Williamson gage. Because flow data for the canal are sparse, there is large uncertainty in correcting Williamson River streamflow for the change in point of diversion. Consequently the streamflow at the Williamson gage was not used in the analysis. The inability to use the Williamson gage for the analysis was not a major deficiency, however, because most diversions within the Williamson River Basin occur in the Sprague River subbasin; therefore, the Sprague River streamflow data were considered a reasonable proxy for evaluating the impacts of regulation for the entire Williamson River Basin during the irrigation season.

\section{Wood River Basin}

Gaging stations have been operated intermittently on the Wood River since 1913. However, the data are not easily compared because the stations have been operated at different locations that are affected differently by tributary inflow, return flow, and diversions. In addition, the periods of record are short, ranging from about 1 to 14 years. The longest period of record of recent daily streamflow data collection is at Wood River at Dixon Road (11502940) from 2006 to 2013 by OWRD, but that gage is located at the upper end of the watershed just below the headwater springs and above all of the diversions, and thus could not be used in the analysis. The Wood River at Dike Road near the mouth gage (11504115), however, has a period of miscellaneous measurements made by the USGS, Klamath Tribes, and Graham Matthews and Associates (GMA) over the period 2003-2013 that could be used to evaluate Wood River streamflows. (GMA and Klamath Tribes data provided by Kris Fischer, Klamath Tribes, written commun., November 13, 2013). 
Table 1. Streamflow-data-collection sites in and near the Upper Klamath Lake Basin, Oregon, used for the analyses in this study.

[OWRD, Oregon Department of Water Resources]

\begin{tabular}{clccc}
\hline $\begin{array}{c}\text { USGS Station } \\
\text { Number }\end{array}$ & \multicolumn{1}{c}{ Site Name } & $\begin{array}{c}\text { Drainage area } \\
\left(\mathrm{mi}^{2}\right)\end{array}$ & $\begin{array}{c}\text { Period of } \\
\text { record }\end{array}$ & Agency \\
\hline 11501000 & Sprague River near Chiloquin & 1,565 & $1920-2013$ & USGS \\
11502500 & Williamson River below Sprague River & 3,000 & $1917-2013$ & USGS \\
11504115 & Wood River mouth at Dike Road & 78.8 & 2013 & USGS \\
10384000 & Chewaucan River near Paisley & 267 & $1912-2013$ & USGS/ \\
& & & & OWRD \\
\hline
\end{tabular}

\section{Methods}

The following methods were evaluated for use in estimating the difference between measured streamflow and CIY-adjusted streamflow:

1. Streamflow Method: For the defined period (WY 1973-2012) in the Sprague River Basin, a Composite Index Year was created from 6 years of record that had streamflow in spring that was similar to that in 2013.

2. Baseflow Method: Hydrographs in each year of record were separated into their baseflow (groundwater) and surface-water runoff components. A baseflow CIY was created and compared to baseflow calculated from the 2013 measured stream hydrograph. This method reduces the effects of precipitation-caused runoff events.

3. Miscellaneous Streamflow Measurements: Owing to the lack of long-term gaging stations in the Wood River Basin, miscellaneous streamflow measurements made in previous years were compared to 2013 values.

Other methods considered but not used involved index stations, hydrographic comparisons, and analysis of the Upper Klamath Lake storage. Assumptions required for those methods proved to be invalid and/or the methods had large uncertainty in the results, and were not used.

\section{Definition of Hydrographs Used in the Analysis}

Four hydrograph types were used in the streamflow-gain calculations described in this report (figs. 3 and 4):

1. Measured 2013 Hydrograph -The amount of streamflow or baseflow measured at a streamflow gaging station over time.

2. Composite Index Year(CIY) Hydrograph — A hydrograph of the average daily streamflow or baseflow for a set of years most similar to WY 2013 streamflows during the Spring Recession period, as defined in the section "Development of the Composite Index Year for the Streamflow and Baseflow Methods.”

3. CIY-Adjusted Hydrograph-The Equilibrated Regulation period of the CIY hydrograph corrected for the average difference between the measured 2013 hydrograph and the CIY hydrograph during the Spring Recession period (see "Streamflow Method" section). The CIYadjusted hydrograph is an attempt to approximate the no-regulation 2013 hydrograph (see below) for purposes of 
calculating the amount of streamflow gained by regulation of diversions.

\section{No-Regulation 2013 Hydrograph-}

Represents the actual shape of the 2013 hydrograph had there been no diversion regulation. Because it is impossible to know what that hydrograph would look like because there were no diversions in 2013, it is conceptual.

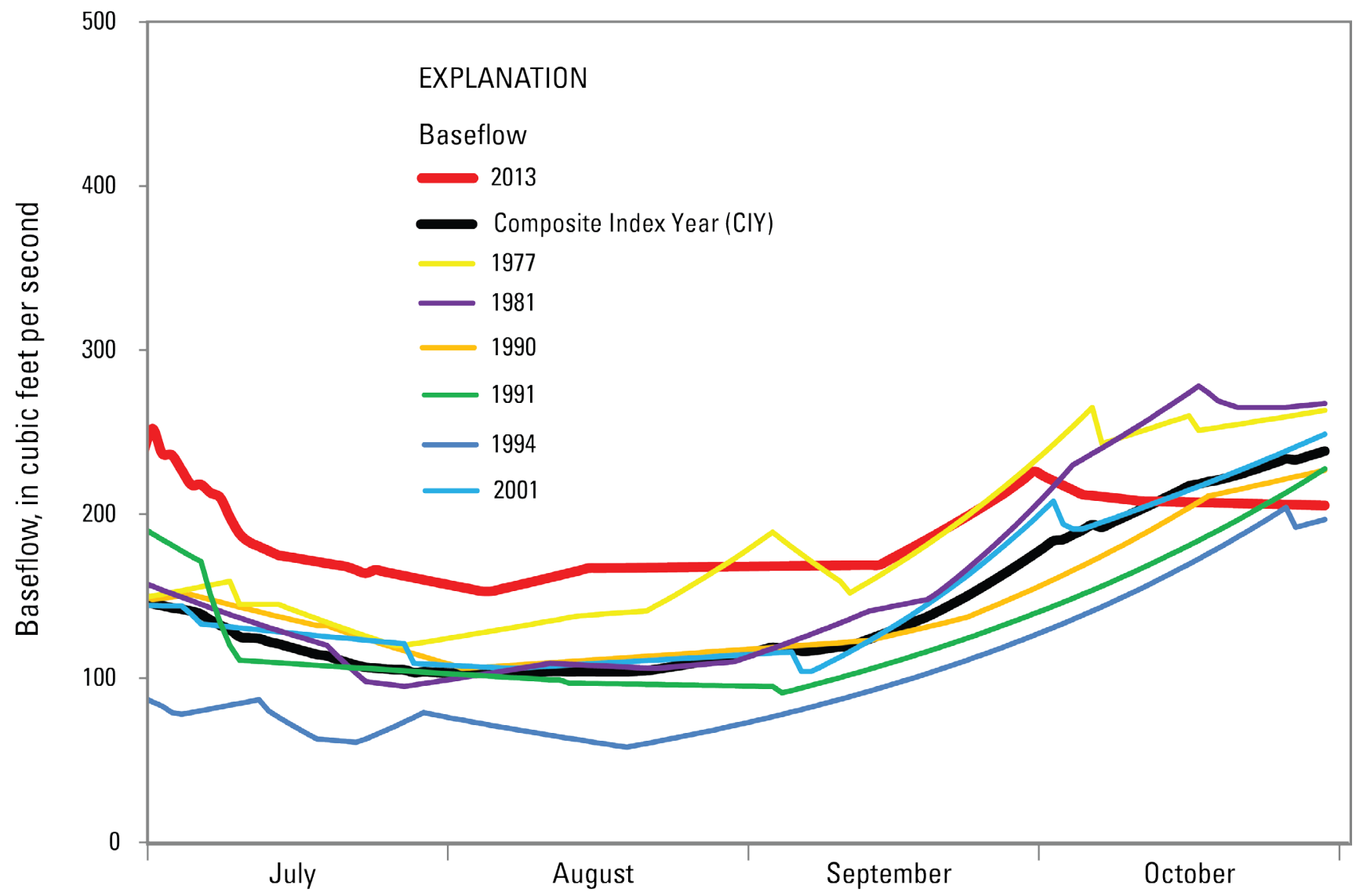

Figure 3. Measured 2013 baseflow hydrograph, composite index year baseflow (CIY) hydrograph, and component years of the CIY baseflow hydrographs for the Sprague River streamflow gage, Upper Klamath Lake Basin, Oregon. 


\section{Development of the Composite Index Year for the Streamflow and Baseflow Methods}

Historical records for the Sprague River for WY 1973-2012 were evaluated for both the Baseflow and Streamflow Methods to find the years during which the spring recession most closely resembled that measured during 2013 and a CIY hydrograph created to define the shape of the CIY-adjusted hydrograph. For each year, the difference between WY 2013 streamflow and that for each candidate year was calculated for each 7day moving average between May 1 and June 15 . Two error metrics were evaluated: the mean error between years (bias) and the mean absolute error between years (general fit)(table 2). Low mean error between a candidate year and 2013 suggests that the total amount of streamflow during May 1-June 15 was similar, but mean error does not account for the shapes of the hydrographs or the timing of the peaks. Candidate years with low mean absolute error have similarly shaped hydrographs, but mean absolute error does not account for bias in either direction (more or less total water).

In general, years with low mean errors tended to have low mean absolute errors and vice-versa. For the Sprague gage (11501000), WY 1977, 1981, 1990, 1991, 1994, and 2001 had the lowest of both error metrics of all candidate comparison years to WY 2013 and were chosen for inclusion in the CIY (fig. 3). Three of these years had less streamflow during the spring recession period than 2013 (1977, 1994, and 2001), whereas three had more streamflow for the same period (1981, 1990, and 1991). This distribution of relatively dry and wet spring recession periods provided an appropriate balance for the analysis.
Table 2. Best-fit evaluation of candidate years for Sprague gage (station 11501000) baseflows for the Composite Index Year, May 1-June 15

[Years are ranked from lowest to highest mean error and mean absolute error.]

\begin{tabular}{lcc}
\hline \multicolumn{1}{c}{ Metric } & Mean error & $\begin{array}{c}\text { Mean absolute } \\
\text { error }\end{array}$ \\
\hline Best Fit & 1990 & 1994 \\
2nd best fit & 1977 & 2001 \\
3rd best fit & 1994 & 1977 \\
4th best fit & 2001 & 1990 \\
5th best fit & 1981 & 1981 \\
6th best fit & 1991 & 1991 \\
7th best fit & 2004 & 2004 \\
8th best fit & 1988 & 1988 \\
9th best fit & 1987 & 1987 \\
10th best fit & 1992 & 1992
\end{tabular}

The anomalous October-November 2013 baseflow decline (fig. 3) probably resulted from much less than average precipitation beginning in fall. Average precipitation for Klamath Falls in the months of October and November are 1.03 and 1.83 inches, respectively (Western Regional Climate Center, 2012). In 2013, October and November precipitation totals were 0.01 and 0.34 inch, respectively (MesoWest, 2013). For years used in the creation of the CIY and most other years, there is a general trend of increasing flow from early September through November as less water is diverted and precipitation increases. 


\section{Streamflow Method}

The Streamflow Method involves (1) creating a CIY hydrograph to define the shape of the CIY-adjusted streamflow hydrograph, (2) comparing the difference between the CIY and 2013 measured Spring Recession streamflows to determine the difference in streamflow magnitude (offset) between the measured and CIY hydrographs and, hence, the CIY-adjusted streamflows for the rest of the water year, and (3) comparing the CIY-adjusted streamflows and measured streamflows during the Equilibrated Regulation period to determine the effects of diversion regulation on the measured streamflow.

The purpose of the offset in step 2 is to normalize the CIY streamflows for measured 2013 streamflows: Although the Spring Recession hydrographs for the years that compose the CIY are closest to the 2013 Spring Recession hydrograph, the CIY and 2013 Spring Recession hydrographs were not identical in terms of average streamflow. Application of the offset was made with the assumption that the average difference in streamflow magnitude between the two Spring Recession hydrographs would have persisted through the Equilibrated Regulation period had no regulation occurred. To determine the offset, the difference between 2013 measured streamflow and the CIY streamflow was determined for each day during Spring Recession period (May 1-June 15) and an average difference calculated for the period. This value was applied to the CIY hydrograph to establish the CIY-adjusted streamflow, which was developed to represent hypothetical conditions of normal diversion.

As a check on the assumption that the CIY hydrograph (and, by extension, the CIY-adjusted hydrograph) represents reasonable streamflow conditions for comparison to the 2013 streamflow, the offsets between the CIY and measured 2013 hydrographs for the periods before and after the Equilibrated Regulation period were compared (fig. 4).(The CIY-adjusted and no-regulation hydrographs are shown for reference.) For the Spring Recession period, the average 2013 streamflow at the Sprague gage was $32 \mathrm{ft}^{3} / \mathrm{s}$ lower than in the CIY. If the CIY and measured 2013 hydrographs compared well, then in October, when streamflow diversions generally have ceased, the measured 2013 streamflow should once again be approximately $32 \mathrm{ft}^{3} / \mathrm{s}$ less than the CIY streamflow for the same period. A large rain storm in late September-early October in 2013 caused an increase in Sprague River streamflow, but once the streamflow stabilized around October 7, 2013, the relation of the measured 2013 hydrograph to the CIY hydrograph returned to the pre-diversion-shutoff condition before flattening out due to abnormally low precipitation (fig. 4). For the 21-day period of October 8-28, the average 2013 streamflow was $31 \mathrm{ft}^{3} / \mathrm{s}$ lower than for the CIY, a $1-\mathrm{ft}^{3} / \mathrm{s}$ difference between the Spring Recession and Post-Regulation periods. The small magnitude of this difference suggests that the adjusted-CIY hydrograph and no-regulation hydrograph were of similar magnitude before and after the Equilibrated Regulation Period, although this result gives no information about the shape or magnitude of the no-regulation hydrograph during the same period. A larger difference before and after the Equilibrated Regulation Period would have suggested a divergence between the adjusted-CIY hydrograph and noregulation hydrograph at some point. 


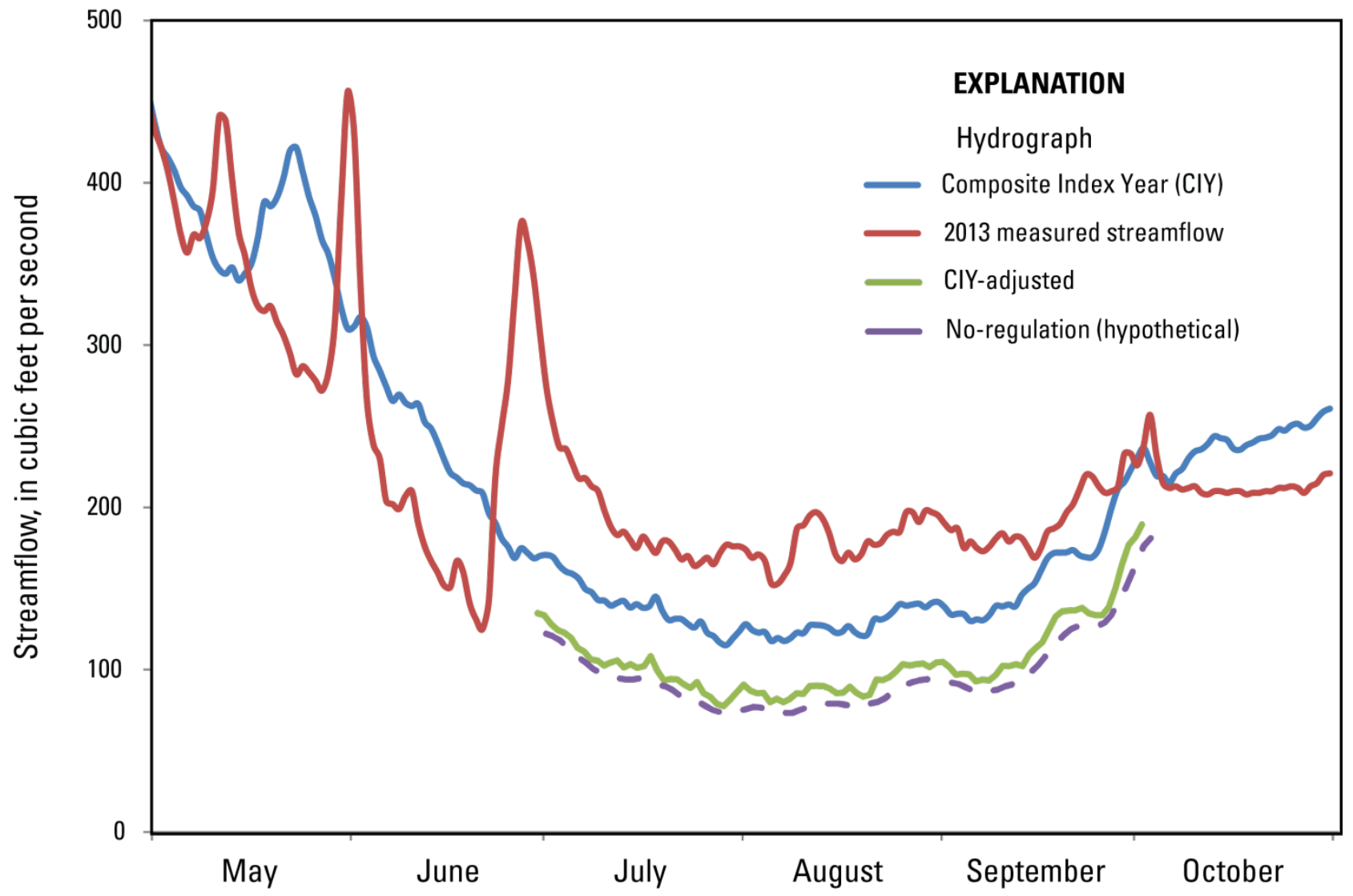

Figure 4. Comparison of 2013 measured streamflow to CIY streamflow at the Sprague River streamflow gage, Upper Klamath Lake Basin, Oregon. The CIY-adjusted and no-regulation hydrographs are shown for reference.

Once the CIY-adjusted streamflow hydrograph was established, the difference between it and the 2013 measured streamflow at the Sprague gage during the Equilibrated Regulation period (July 1-September 30) was determined. The resulting value represents the change in streamflow between the two hydrographs and is a measure of the effect of regulation of diversions on streamflow.

The CIY-adjusted hydrograph was created to approximate the shape of the actual 2013 hydrograph if there had been no diversion regulation. It is impossible to know what the shape of the 2013 hydrograph would have been without diversion regulation (the "no-regulation hydrograph" described earlier). The inability to quantify the difference between the CIY-adjusted Hydrograph and the No-regulation Hydrograph makes knowledge of the error inherent in the analysis impossible. Conceptually, however, the fact that the CIY-adjusted hydrograph is based on several low-flow years similar to 2013 makes it likely to be a robust tool.

\section{Baseflow Method}

Streamflow includes both groundwater components and surface-runoff components. Baseflow is the portion of streamflow composed primarily of groundwater. Large pulses of surface runoff from summer precipitation events can result in streamflow hydrographs with pronounced peaks, which make year-to-year comparisons difficult. Comparing hydrographs showing only baseflow minimizes the influence of precipitation events.

Daily baseflow was calculated using the USGS program PART (Rutledge, 1998). PART uses the antecedent streamflow recession to 
separate baseflow from streamflow. If a daily decline of streamflow is less than 0.1 log cycle (10 percent log base 10$)$, streamflow is considered equal to baseflow. The duration of surface-runoff peaks is estimated as:

$N=A^{0.2}$

Where

$N=$ the number of days after the peak, and

$A=$ the drainage area of the watershed, in square miles.

The PART algorithm is executed three times, once using the largest integer (number of days) that is less than the result from equation (1) and once more for each of the next two larger integers. The median of the three integers was used for this analysis, although the results varied little between integers.

PART was applied to the calendar year 2013 measured streamflow to determine baseflow conditions. Figure 5 shows a comparison of the 2013 streamflow hydrograph to the 2013 baseflow hydrograph resulting from the PART analysis. Note how the baseflow hydrograph is less prone to variability caused by precipitation events.

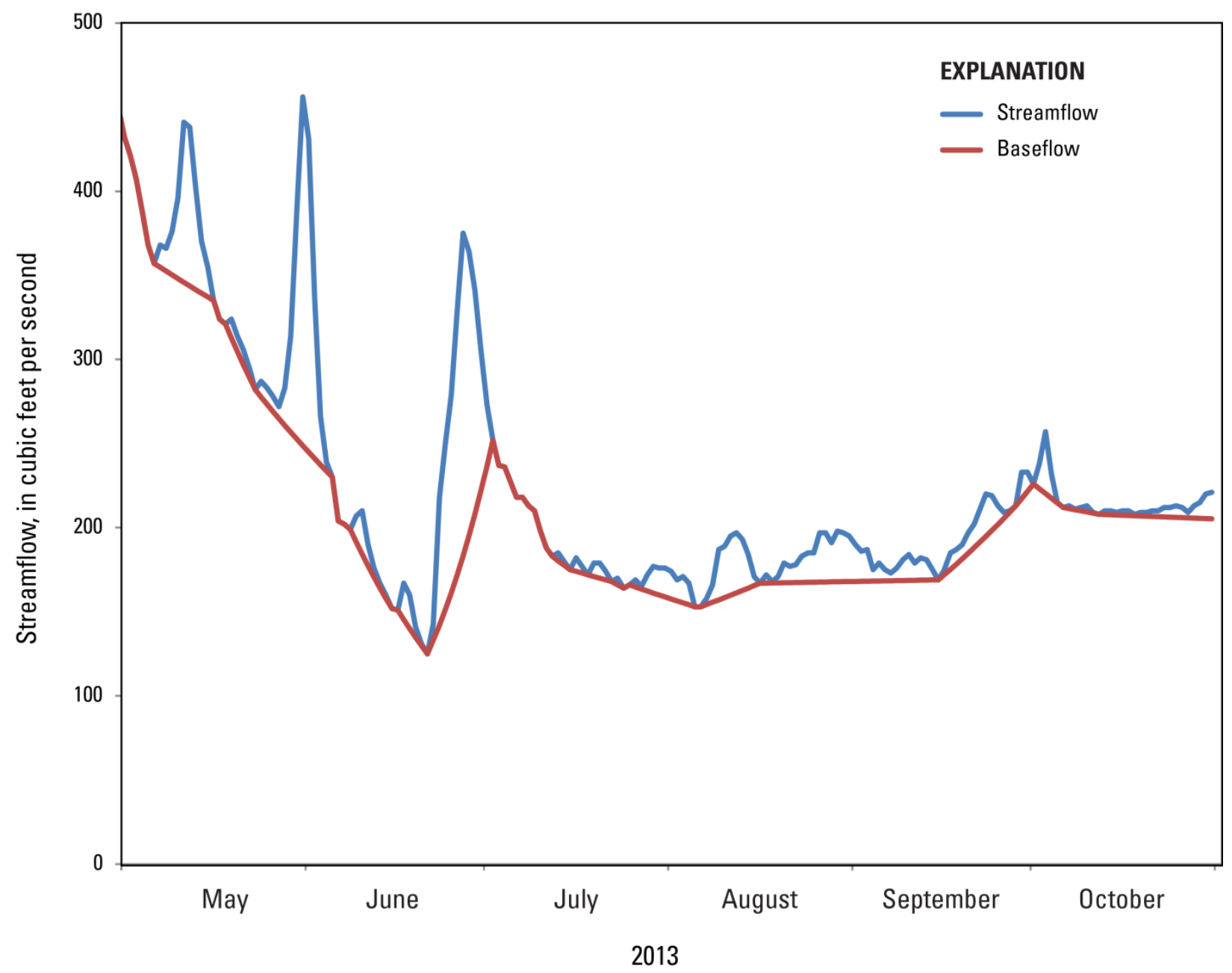

Figure 5. Comparison of measured 2013 streamflow to calculated 2013 baseflow for the Sprague River streamflow gage (11501000), Upper Klamath Lake Basin, Oregon. 
PART was also applied to each year of the 6year CIY, and results from those 6 years were averaged to create the baseflow CIY under normal diversion conditions. Figure 6 compares the 2013 baseflow at the Sprague gage with the CIY baseflow.

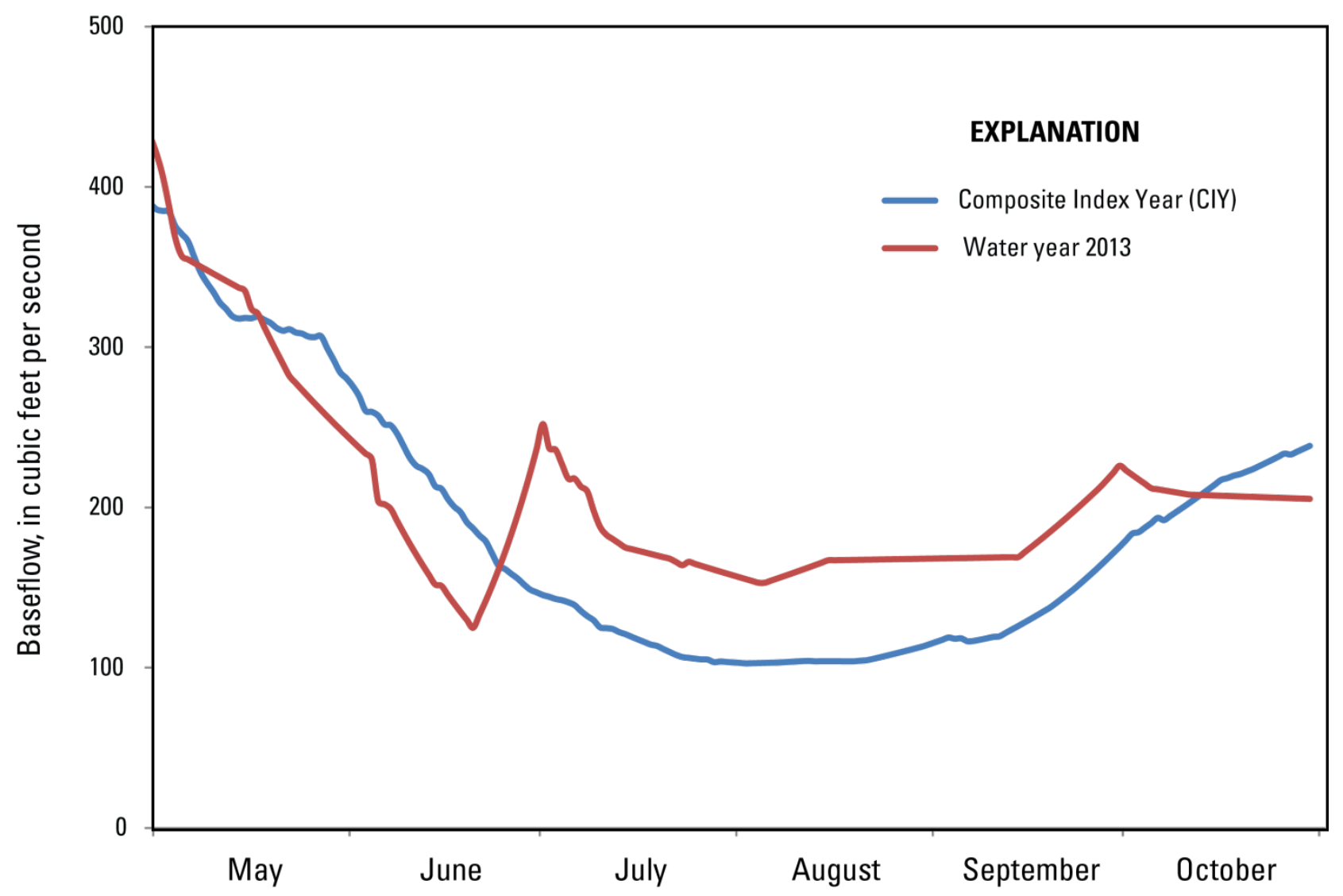

Figure 6. Comparison of 2013 baseflow and CIY baseflow at the Sprague River gage, Upper Klamath Lake Basin, Oregon.

The method of calculation of the change in baseflow between the Spring Recession and Equilibrated Regulation periods was identical to the method described for the Streamflow Method in (1) comparing the difference between the CIY and measured Spring Recession baseflow to determine the offset between the measured and CIY hydrographs and, hence, the CIY-adjusted baseflow for the remainder of the water year, and (2) comparing the CIY-adjusted baseflow and measured baseflow during the Equilibrated Regulation period to determine the effects of regulation on the measured baseflow.
Assumptions in the Baseflow Method are similar to those in the Streamflow Method. The Baseflow Method also assumes the CIY baseflow hydrograph is of similar shape to what the 2013 baseflow hydrograph would have been without diversion regulation (no-regulation 2013 baseflow hydrograph). The use of an antecedent streamflow recession to separate baseflow using the offset requires a hydrograph with a shape similar to what would occur in natural conditions (without large withdrawals or regulation with dams). Withdrawals that markedly alter the receding limb of a hydrograph could affect baseflow calculations. 


\section{Miscellaneous Streamflow Measurement Method for the Wood River Basin}

Long-term streamflow data were not available near the mouth of the Wood River. Consequently, the Streamflow and Baseflow Methods could not be used to estimate the effect of regulation of diversions there. Streamflow data exist for the Wood River near the headwaters at Dixon Road (11502940), but the Dixon Road site is near the headwaters springs above any tributaries or diversions. A measurement site at Dike Road (11504115) near the mouth of the Wood River, however, is downstream of most tributaries, diversions, and return flows, and sufficient data exist for that site to analyze Wood River streamflows. Miscellaneous streamflow measurements were made at the site from 2003 to 2013.

Monthly average values were calculated for WY 2013 and the two previous driest years (2004 and 2007). The average of those 2 years constituted the Wood River CIY. The calculated offset between the CIY and 2013 streamflows was $10.4 \mathrm{ft}^{3} / \mathrm{s}$. For each month during August and September, the CIY average was subtracted from the WY 2013 average. The difference between Wood River CIY and WY 2013 values can be ascribed to the amount of Wood River streamflow not diverted due to regulation.

Several factors prevent an accurate estimate of the amount of streamflow in the Wood River that reached Upper Klamath Lake due to diversion regulation. Rather than continuous streamflow data, the only data available are miscellaneous streamflow measurements. Some months have only a few measurements, and the timing of those measurements may have a marked effect on the estimation of average monthly streamflow. (For example, measurements made after a precipitation event would skew the average higher. As another example, during the Spring Recession period, when streamflow is typically decreasing rapidly, measurements made early in the month are normally higher than measurements made later in the month.) Also, due to the relatively short history of streamflow measurements at Dike Road, the two driest of the previous 8 years of collection (WY 2004 and 2007) were averaged for a CIY, rather than the 6 years most similar to WY 2013, as was done for the Streamflow and Baseflow Methods. Because of these limitations, this method has larger potential error than the Streamflow or Baseflow Methods, but is the only method available for this analysis in the Wood River due to a lack of historical gage data.

\section{Results and Discussion}

The Streamflow, Baseflow, and Miscellaneous Streamflow Measurement methods were used to estimate changes in streamflow to Upper Klamath Lake as a result of WY 2013 diversion regulation in the Williamson River and Wood River Basins, respectively. A comparison of results between the Streamflow and Baseflow Methods for the Sprague gage (table 3) indicated consistency between the methods. 
Table 3. Estimated increase in summer 2013 streamflow from regulation of diversions in the Sprague and Wood River Basins Upper Klamath Lake Basin, Oregon.

[Data for Sprague River Basin from USGS streamflow gaging station Sprague River near Chiloquin (11501000); data for Wood River Basin from streamflow gage Wood River at Dike Road (11504115); $\mathrm{ft}^{3} / \mathrm{s}$, cubic feet per second]

\begin{tabular}{llcc}
\hline \multicolumn{1}{c}{ Method } & \multicolumn{1}{c}{ Period } & $\begin{array}{c}\text { Volume } \\
\text { (acre-feet) }\end{array}$ & $\begin{array}{c}\text { Streamflow } \\
\text { (ft3/s) }\end{array}$ \\
\hline & Sprague River Basin & & \\
\hline Streamflow using 6-year CIY & July-September & 14,100 & 77.2 \\
Baseflow using 6-year CIY & July-September & 14,100 & 77.5 \\
\hline & Wood River Basin & & \\
\hline Miscellaneous streamflow measurements & August & 4,200 & 68.4 \\
& September & 1,300 & 21.7
\end{tabular}

Total estimated increased inflow to Upper Klamath Lake:

19,600

\section{Streamflow Method}

The average difference between the CIY and 2013 streamflow in the Spring Recession period was used to determine the offset between the CIY hydrograph and the 2013 hydrograph and establish the CIY-adjusted streamflows. Streamflow in 2013 at the Sprague gage averaged $32 \mathrm{ft}^{3} / \mathrm{s}$ less than that in the CIY during the Spring Recession period (fig. 4). This offset was accounted for in all calculations made during the July-September Equilibrated Regulation period. For example, the August 1, 2013, streamflow was $174 \mathrm{ft}^{3} / \mathrm{s}$, whereas the CIY streamflow was 128 $\mathrm{ft}^{3} / \mathrm{s}$, which would indicate a net increase from regulation of $46 \mathrm{ft}^{3} / \mathrm{s}$ if not corrected for the difference during the Spring Recession period. However, because the 2013 streamflow during the Spring Recession period was offset on average $32 \mathrm{ft}^{3} / \mathrm{s}$ lower than the CIY streamflow, that value was added to the August 1 difference, resulting in an estimated $78 \mathrm{ft}^{3} / \mathrm{s}$ increase from 2013 regulation on that date.

Each day's increase in streamflow due to regulation, in cubic feet per second, was converted to acre-feet and then summed for July 1-September 30 to calculate a total volume for the period. The adjusted average increase in streamflow due to 2013 regulation during the Equilibrated Regulation period (July 1September 30) was $77.2 \mathrm{ft}^{3} / \mathrm{s}$, which is approximately 14,100 acre-ft (acre-feet, rounded) for the period (table 3 ).

\section{Baseflow Method}

Average baseflow during the Spring Recession period in 2013 at the Sprague gage was $20 \mathrm{ft}^{3} / \mathrm{s}$ less than the baseflow for the CIY. Consequently, an offset of $20 \mathrm{ft}^{3} / \mathrm{s}$ was added to the difference between 2013 and CIY baseflow for the Equilibrated Regulation period to create the CIY-adjusted hydrograph. Seven-day moving 
averages of baseflow were evaluated to reduce the effect of individual storm events on average baseflow. The adjusted increase in baseflow at the Sprague gage during the Equilibrated Regulation period was $77.5 \mathrm{ft}^{3} / \mathrm{s}$ (fig. 5), equating to a baseflow increase of approximately 14,100 acre-ft for the period. This volume is nearly identical to the results from the Streamflow Method analysis, even though the calculation of baseflow using PART effectively removes several 2013 runoff events and subsequent streamflow increases resulting from late-summer rainfall.

After weighing the validity of the assumptions, data requirements, and restrictions for each method, it was determined that the Baseflow Method was the most appropriate approach for determining the effects of regulation on the Sprague River because it eliminates the potential effects of summer precipitation events on the analysis.

\section{Miscellaneous Streamflow Measurement Method for the Wood River Basin}

To estimate the increase in streamflow in the Wood River from regulation of diversions in the Wood River Basin, average 2013 streamflow measurements at Dike Road (11504115) in August and September were compared to average streamflow measurements in the same months from 2004 and 2007, which composed the Wood River CIY.

During the Spring Recession period (May 1June 15), the difference between the 2013 average streamflow measurements and the CIY average streamflow measurements in the Wood River Basin became progressively smaller (table 4). June is the last full month before surfacewater diversion regulation began. The average of the 2013 Wood River streamflow measurements during the Spring Recession period was $10.4 \mathrm{ft}^{3} / \mathrm{s}$ lower than the CIY average.

In August, the first full month of Wood River Equilibrated Regulation period, the average 2013 streamflow measurement was $58 \mathrm{ft}^{3} / \mathrm{s}$ higher than the CIY average. With the offset this is an estimated increase in streamflow from regulation of surface-water diversions of 68.4 $\mathrm{ft}^{3} / \mathrm{s}$ (about 4,200 acre-ft, rounded) (table 3). For September, the difference between measured 2013 streamflow and the CIY streamflow was $11.3 \mathrm{ft}^{3} / \mathrm{s}$. Applying the offset gives an estimated gain of $21.7 \mathrm{ft}^{3} / \mathrm{s}$ (about 1,300 acre-ft, rounded). Combining the gains from regulation of diversions during August and September gives a total of about 5,500 acre-ft. As has been explained previously, the lack of long-term data for the Wood River Basin makes these calculations approximate. 
Table 4. Comparison of Wood River streamflow near the mouth (11504115) for the 2003-2013 irrigation seasons in the Upper Klamath Lake Basin, Oregon.

$\left[\mathrm{ft}^{3} / \mathrm{s}\right.$, cubic feet per second]

\begin{tabular}{|c|c|c|c|c|c|c|c|c|}
\hline & April & May & June & July & August & September & October \\
\hline & & \multicolumn{7}{|c|}{ Period } \\
\hline Year & Parameter & \multicolumn{3}{|c|}{ Spring Recession } & Transition & \multicolumn{2}{|c|}{ Equilibrated Regulation } & $\begin{array}{c}\text { Post- } \\
\text { Regulation }\end{array}$ \\
\hline $\begin{array}{l}2004 \text { and } \\
2007\end{array}$ & $\begin{array}{l}\text { Average streamflow } \\
\left(\mathrm{ft}^{3} / \mathrm{s}\right)\end{array}$ & 402 & 283 & 240 & 244 & 254 & 347 & 431 \\
\hline \multirow[t]{2}{*}{ CIY } & $\begin{array}{l}\text { Streamflow range } \\
\left(\mathrm{ft}^{3} / \mathrm{s}\right)\end{array}$ & $354-473$ & 249-331 & $108-313$ & $199-313$ & $213-300$ & 303-391 & $420-448$ \\
\hline & $\begin{array}{l}\text { Number of } \\
\text { observations }\end{array}$ & 5 & 3 & 6 & 6 & 7 & 6 & 3 \\
\hline \multirow[t]{4}{*}{2013} & $\begin{array}{l}\text { Average streamflow } \\
\left(\mathrm{ft}^{3} / \mathrm{s}\right)\end{array}$ & 376 & 272 & 229 & 279 & 312 & 358 & 387 \\
\hline & $\begin{array}{l}\text { Streamflow range } \\
\left(\mathrm{ft}^{3} / \mathrm{s}\right)\end{array}$ & $372-380$ & 272 & 170-297 & $247-315$ & $281-353$ & $332-383$ & $363-411$ \\
\hline & $\begin{array}{l}\text { Number of } \\
\text { observations }\end{array}$ & 2 & 1 & 3 & 8 & 7 & 2 & 3 \\
\hline & $\begin{array}{l}\text { Difference between } \\
\text { CIY and } 2013\left(\mathrm{ft}^{3} / \mathrm{s}\right)\end{array}$ & -26.1 & -10.8 & -10.4 & 34.6 & 58.0 & 11.3 & -44.7 \\
\hline
\end{tabular}

\section{Sensitivity Analyses}

Sensitivity analyses were performed to examine the effect of altering the number of candidate years in the Baseflow Method CIY on the calculation of baseflow increase from the diversion regulation.

\section{Number of CIY Years}

In the first analysis, baseflow CIYs consisting of 4, 5, 6, 7, 8, 9, and 10 years (table 2) with the lowest mean error statistics at the Sprague gage were evaluated (table 5). For the Baseflow Method analysis at the Sprague gage, the estimated increase in streamflow ranged from 3,360 to 19,400 acre-ft. The largest outlier in this group is the CIY incorporating 4 candidate years.
Three of the 4 years in the 4-year CIY had less streamflow during the Spring Recession period than 2013. Conversely, every year with mean error values ranked from $5^{\text {th }}$ to $9^{\text {th }}$ had more baseflow during the Spring Recession period than 2013. Whenever a year was added to the CIY that had more Spring Recession streamflow than 2013, the resulting calculation estimated an increase in summer 2013 streamflow from regulation of diversions. Conversely, adding years to the CIY that had less Spring Recession baseflow than 2013 had the opposite effect. These results underscore the importance of finding a balance between years with more or less streamflow than the year of interest when constructing the CIY and of the sensitivity to the number of years chosen for the CIY. 
Table 5. Results of the number of years in the CIY sensitivity analysis for the Baseflow Method of determining streamflow increases resulting from regulation of diversions in the Sprague River Basin, Oregon, in 2013.

[ $\mathrm{ft}^{3} / \mathrm{s}$, cubic feet per second]

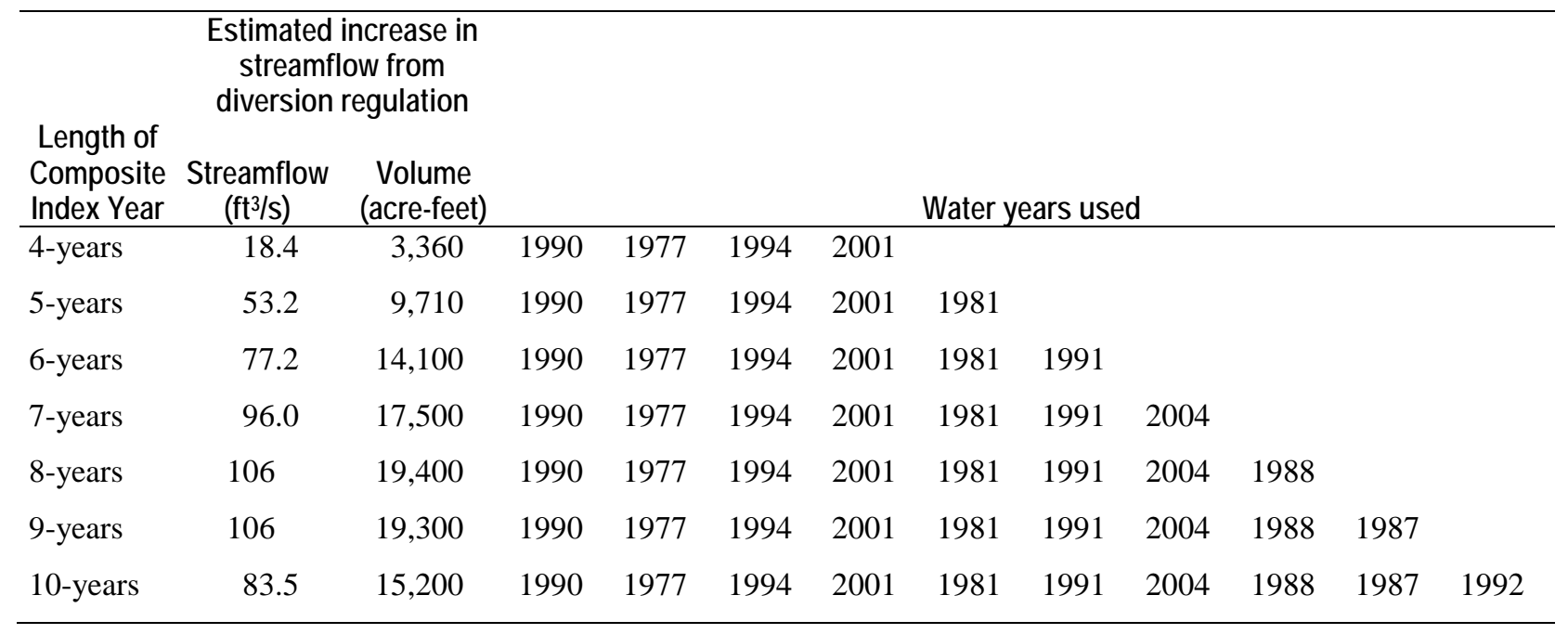

\section{CIY Baseflow Patterns}

In a second sensitivity analysis, each of the 6 years in the CIY was analyzed using the Streamflow and Baseflow Methods and was ranked on the basis of streamflow during the
May-June period and July-September period compared to the other 40 years considered for this study in the 1972-2012 period of record (table 6). The year with the least baseflow was given a "dryness rank" of 1 , and the year with the most baseflow a rank of 41 .

Table 6. Results of the ranking of CIY sensitivity analysis for the Streamflow and Baseflow Methods of determining streamflow increases as a result of diversion regulation in the Sprague River Basin, Oregon, in 2013.

\begin{tabular}{ccccc}
\hline Water Year & $\begin{array}{c}\text { Streamflow } \\
\text { method } \\
\text { (acre-feet) }\end{array}$ & $\begin{array}{c}\text { Baseflow } \\
\text { method } \\
\text { (acre-feet) }\end{array}$ & $\begin{array}{c}\text { Rank of May-June } \\
\text { streamflow, 1972-2012, } \\
\text { driest = rank of 1 }\end{array}$ & $\begin{array}{c}\text { Rank of July- } \\
\text { September streamflow, } \\
\text { 1972-2012, } \\
\text { driest = rank of 1 }\end{array}$ \\
\hline 1990 & 12,317 & 10,176 & 5 & 12 \\
1977 & 23,827 & 22,404 & 4 & 17 \\
1994 & $-2,185$ & -922 & 3 & 1 \\
2001 & 12,338 & 9,506 & 2 & 14 \\
1981 & 1,060 & -837 & 7 & 10 \\
1991 & 30 & 3,347 & 8 & 9 \\
\hline
\end{tabular}


Three of the 6 CIY years investigated (1977, 1990, and 2001) had considerable increases in rank between the May-June period and the JulySeptember period. In other words, each of these 3 years had little streamflow relative to the other 40 years of consideration in the spring, but had more moderate streamflow levels in the summer, presumably after summer precipitation events or late snowmelt. Conversely, the other 3 CIY years investigated (1981, 1991, and 1994) had consistent ranks between the two periods.

As mentioned previously, the no-regulation hydrograph is a theoretical hydrograph that represents what streamflow would have been in 2013 had diversions occurred as usual. The inherent accuracy of the Streamflow and Baseflow Methods depends on the similarity of the shape of the no-regulation 2013 hydrograph compared to that of the years used in the CIY. If the no-regulation 2013 streamflow hydrograph were to show a moderate increase in rank between the Spring Recession and Summer Equilibrated periods, the CIY hydrograph would likely resemble the no-regulation 2013 hydrograph. If the no-regulation 2013 hydrograph were to remain low in rank through both periods, the shape of the CIY would lead to an underestimation of the amount of streamflow that reached the Upper Klamath Lake due to diversion regulation. Lastly, if the no-regulation 2013 hydrograph were to show a considerable increase in rank between the Spring Recession and Summer Equilibrated periods, the Streamflow and Baseflow Methods would overestimate the streamflow gains from regulation.

Although the no-regulation 2013 hydrograph for the Sprague gage is conceptual, to approximate it streamflow data from the gage Chewaucan River near Paisley, Oregon (10384000, operated by OWRD) (table 1, fig. 1) in an adjacent basin were analyzed using the same ranking techniques. The Chewaucan River Basin is smaller than the Sprague River Basin, but like the Sprague River, the Chewaucan River is in the semi-arid Great Basin, is fed by spring and summer snowmelt, and has agricultural diversions in summer. Chewaucan and Sprague River streamflows during the Spring Recession period are highly correlated (fig. 7). For the May-June period, 2013 had the $9^{\text {th }}$-lowest streamflow of the 41 years analyzed for the Chewaucan gage, whereas for the July-

September period, 2013 ranked as the $14^{\text {th }}$ lowest. The streamflow in the Sprague River for years in the CIY and for Chewaucan streamflow in 2013 both show a similar rank in dryness in the spring and similar increase in rank in summer, which supports using the CIY as a proxy for 2013 Sprague River streamflow with no regulation in the Streamflow and Baseflow methods. 


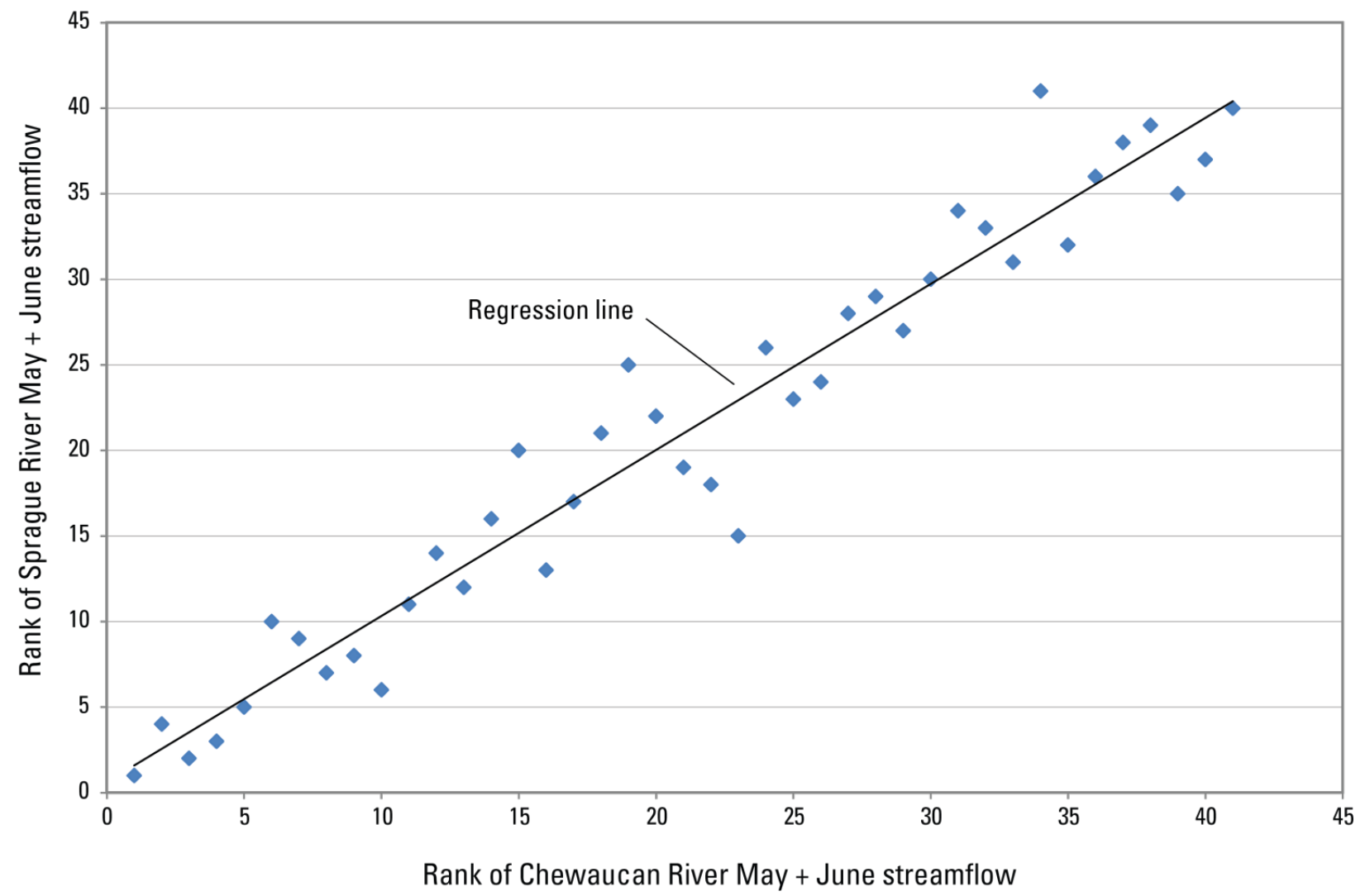

Figure 7. Comparison of the dryness rank of the May-June streamflow for the Sprague and Chewaucan River streamflow gages for 1972-2012. Regression equation: $y=0.9706 x+0.6183, R^{2}=0.942$

\section{Method Uncertainties and Suggestions for Improvement}

This section discusses sources of uncertainty that could affect method reliability and suggests possible improvements to the approach that could reduce these uncertainties.

\section{Method Uncertainties}

\section{Uncertainty Due to Water Management}

Groundwater is a major component of streamflow in the Upper Klamath Lake Basin (Hubbard, 1970; Gannett and others, 2007), and groundwater pumping captures water that contributes to streamflow and reduces flow in the stream. The analysis in this report assumed that 2013 groundwater pumping in the Sprague River Basin was similar to that in the years used in the CIY although increases in acres irrigated by groundwater have increased over time (Gannett and others, 2007, fig. 19). Increases in groundwater pumping that might have resulted from 2013 restrictions on surface-water diversions were not factored into the analysis. Given the current lack of knowledge concerning the specific effect of groundwater withdrawals on Sprague River streamflow, there was no way to quantify this effect.

The methods developed in this study to construct the CIY-adjusted hydrograph assumed that 2013 stream diversions during the Spring Recession period were similar to the diversions in years used in the CIY. If spring diversions were different, the differences in streamflow and baseflow calculated during the 2013 Equilibrated Regulation period may not be completely attributable to regulation of diversions. 
Uncertainty Due To Climatic Variation or Land-Use Changes

The analysis assumed that climatic and land use conditions in 2013 were similar to conditions in the years of the CIY. If climate or land use conditions differed, then evapotranspiration of water in the watershed might have been different, which might have resulted in changes in streamflow or baseflow that were not attributable to regulation of diversions.

During the 2013 irrigation season (April 1September 30), several precipitation events occurred, which might have resulted in possible additional streamflow. Although the baseflow program PART is designed to separate the base streamflows from runoff occurring from these precipitation events based on hydrograph shape, the other methods did not account for this possible additional streamflow. Annual variation in the amounts of summer precipitation could result in dissimilar hydrograph shapes, which is contrary to the assumption of no major summer precipitation in the Streamflow Method and to a lesser extent, the Baseflow Method. The offset used in the CIY was based on the basic shape of the 2013 spring recession hydrograph. Even though precipitation events changed the shape of the hydrograph, the offset was used for the entire irrigation season (Equilibrated Regulation period).

\section{Suggestions for Improvement: Data Needs for Refining Streamflow Estimates}

The Williamson River Basin has a long-term record of streamflow at several locations that was used to quantify 2013 streamflow increases from regulation of diversions. However, no comparable streamflow data set exists for the Wood River Basin. Continuous streamflow data collection at the gaging station at the mouth of the Wood River at Dike Road began in the summer of 2013 in cooperation with the Bureau of Reclamation and USGS. This new gage will improve quantification of Wood River flows into Upper Klamath Lake.
More documentation of the measurement of diversion flows (both groundwater and surface water) and the irrigation return flows (tailwater) throughout the Upper Klamath Lake Basin would greatly improve the quantification of net streamflows into Upper Klamath Lake.

Within the Williamson and Wood River Basins, a better knowledge of streamflow gains and losses due to diversions, return flows, and groundwater gains or losses in reaches between current gaging stations through seepage studies would help clarify the spatial effect of regulation and irrigation return flows on streamflow. Return flows from irrigation diversions in the basins were not considered for this study and could be important. Suggested site locations (La Marche, 2011, p. 125-130, table VI) and reaches within the basin where groundwater discharge has been estimated are mentioned in Gannett and others (2007, p.22, table 6). Additional streamflow data from currently gaged reaches could also help refine estimates.

\section{Summary}

Upper Klamath Lake Basin, the area drained by the tributaries to Upper Klamath Lake, predominantly the Wood River system and the Williamson River system, is important for agriculture and aquatic habitat in southern Oregon. In 2013, the Upper Klamath Lake Basin had a dry spring, resulting in an executive order declaring a drought emergency in Klamath County signed by Oregon Governor Kitzhaber on April 18, 2013. On June 10, 2013, priority "calls" were delivered to the Oregon Water Resources Department (OWRD) requesting that OWRD curtail junior water-right diversions to protect senior water rights. In response to the priority calls, OWRD personnel, over the following months, gradually shut off most surface-water diversions from streams within the basin. Water managers asked the U.S. Geological Survey (USGS) to estimate the increase in streamflow resulting from the priority calls. This unusual basinwide regulation of surface-water diversions 
was a unique opportunity to evaluate the effects of water-right regulation on streamflows.

The USGS, in cooperation with the Bureau of Reclamation, evaluated methods to quantify the increase in streamflow to Upper Klamath Lake resulting from the regulation of diversions. Two streams account for most of the streamflow into the lake: the Williamson and Wood Rivers. Three methods were used to quantify those increases in streamflows to Upper Klamath Lake.

Streamflows from water years 1973 to 2012 were evaluated to identify years with hydrographs similar to water year 2013, as measured at the Sprague River gage near Chiloquin (USGS station 11501000). (The Sprague River is the main tributary to the Williamson River.) Sprague River streamflow data were used as a reasonable proxy for evaluating the impacts of regulation on the entire Williamson River Basin during the irrigation season. The best fit 6 years $(1977,1981,1990$, 1991, 1994, and 2001) were combined to calculate a Composite Index Year (CIY). The streamflows were then adjusted to account for baseflow using antecedent streamflow recession methods. The increase in streamflow attributable to the 2013 diversion regulation was the difference between the 2013 measured baseflow and the CIY baseflow. This method (the "Baseflow Method") was considered to result in the most appropriate approximation of the increase in streamflow from regulation of diversions because it reduces the effect of irrigation-season precipitation events on the calculations. For the Williamson River Basin, the estimated increase in streamflow from regulation of diversions in 2013 was 14,100 acre-feet. The "Streamflow Method" (the difference between the 2013 measured streamflow and the CIY streamflow), despite a major precipitation event in July, produced similar results to the Baseflow Method.

Quantifying the change in streamflow from regulation of diversion for the Wood River Basin was problematic due to a lack of long-term streamflow information, so another comparison method was used in the Wood River evaluation. An increase in streamflow from regulation of diversions in the Wood River Basin of roughly 5,500 acre-ft was estimated by comparing the average August and September miscellaneous streamflow measurements in 2013 with historical August and September streamflow measurements. Summing results for both stream systems (Williamson and Wood Rivers) provides an estimate of the change in streamflow into Upper Klamath Lake from 2013 regulation of diversions of 19,600 acre-ft.

Other estimation methods were investigated but were found to be less accurate than the study methods and were not used in this study. The report discusses sensitivity analyses and method assumptions, and identifies further studies and data collection that could improve the accuracy of estimated yield from diversion regulation.

\section{Acknowledgments}

The authors gratefully acknowledge the support of the water managers of the Williamson, Sprague, and Wood Rivers. Our understanding of the surface-water hydrology of the Williamson, Sprague, and Wood Rivers, benefited tremendously from many hours of discussions with the scientists working in the basin, who freely shared observations, insights, and valuable data. Particular thanks go to Dave Felstul and Matthew Kritzer of the Bureau of Reclamation, Klamath Basin Area Office; Doug Woodcock, Ken Stahr, Jonathan La Marche, Richard Marvin, and Kyle Gorman of the Oregon Water Resources Department; Terry Fisk of the U.S. Fish and Wildlife Service; and Larry Dunsmoor and Kris Fischer of the Klamath Tribal Nation. 


\section{References Cited}

Burt, Charles, and Freeman, Beau, 2003, Klamath Basin Investigation-Hydrologic assessment of the Upper Klamath Basin-Issues and opportunities, Draft report: San Luis Obispo, California, California Polytechnic State University, Irrigation Training and Research Center (ITRAC), Prepared for the U.S. Bureau of Reclamation, May, 2003, variously paged.

Gannett, M.W., Lite, K.E. Jr., La Marche, J.L., Fisher, B.J., and Polette, D.J., 2007, Groundwater hydrology of the upper Klamath Basin, Oregon and California: U.S. Geological Survey Scientific Investigations Report 20075050, 84 p., http://pubs.usgs.gov/sir/2007/5050/

Hubbard, L.H., 1970, Water budget of Upper Klamath Lake southwestern Oregon: U.S Geological Survey Hydrologic Investigations Atlas HA-351.

Klamath Tribes, 2013, Klamath Tribes of Oregon press release-Klamath Tribes historic treaty water right call: http://www.klamathtribes.org/Klamath\%20Trib es\%20Press\%20Release\%20Water\%20Call.pdf , accessed January 21, 2014.

La Marche, J.L., 2011, OWRD Stream gaging network evaluation for water distribution: Oregon Water Resources Department Open File Report SW 2011-01, 183 p. http://www.oregon.gov/owrd/PUBS/docs/report s/SW_2011_001_Stream_gaging_network_eval uation.pdf

MesoWest, 2013, Download KLMT Data: http://mesowest.utah.edu/cgibin/droman/download_ndb.cgi?stn $=K L M T \& h o$ ur $1=15 \& \min 1=25 \&$ timetype $=$ LOCAL\&unit $=0$ \&graph $=0$ ", accessed 6/2/2014.
Natural Resources Conservation Service, 2004, Summary of the upper Klamath Basin rapid subbasin assessment of private lands: U.S. Department of Agriculture, Natural Resources Conservation Service, variously paginated.

Natural Resources Conservation Service, 2013a, Oregon state basin outlook report for June 2013: accessed January 21, 2014, at

http://www.wcc.nrcs.usda.gov/cgibin/bor2.pl?stat $e=$ or \&year $=2013 \&$ month $=6 \&$ format $=$ text

Natural Resources Conservation Service, 2013b, Basin-wide precipitation data summary-July 2013: accessed January 21, 2014, at http://www.wcc.nrcs.usda.gov/ftpref/data/clima te/basin_reports/oregon/wy2013/bspror7.txt

Rutledge, A.T., 1998, Computer programs for describing the recession of groundwater discharge and for estimating mean groundwater recharge and discharge from streamflow records-Update: U.S. Geological Survey Water Resources Investigations Report 984148, 52 p., http://pubs.usgs.gov/wri/wri984148/.

U.S. Drought Monitor, 2013, CONUS-June 18, 2013: accessed January 24, 2013, at http://droughtmonitor.unl.edu/data/jpg/201306 18/20130618_conus_text.jpg

U.S. Geological Survey, 2014, USGS 11501000 Sprague River near Chiloquin, OR: http://nwis.waterdata.usgs.gov/or/nwis/uv/?cb_ 00060=on\&cb_00065=on\&format = gif_default \&site_no $=11501000 \&$ period $=\&$ begin_date $=2$ 013-09-01\&end_date $=$ 2014-02-28

Western Regional Climate Center, 2012, Klamath Falls 2 SSW, Oregon-NCDC 1981-2010 monthly normals: http://www.wrcc.dri.edu/cgibin/cliMAIN.pl?or4506 (click on "NCDC 1981-2010 Normals”), accessed 6/2/2014. 


\section{咅}

哭

$\frac{2}{c}$

웅 